\title{
THE OCELOT (LEOPARDUS PARDALIS) IN NORTHERN TEXAS, WITH COMMENTS ON ITS NORTHERN BIOGEOGRAPHY
}

\author{
Frederick B. Stangl Jr. ${ }^{1}$ and John H. Young ${ }^{2}$
}

\begin{abstract}
A road-killed specimen of a large male ocelot (Leopardus pardalis) was salvaged on March 2010 from Palo Pinto County in north central Texas. Our review of the northern biogeography of the species indicates that the specimen is not out of historical context. The possibility that the animal represents a broader range of sparsely distributed individuals within the elusive cat's known historical range deserves consideration.

RESUMEN.-Un ocelote (Leopardus pardalis) muerto de sexo masculino y de tamaño grande fue recuperado en una carretera del Condado Palo Pinto en el centro-norte de Texas en Marzo del año 2010. Una revisión de la biogeografía norteña del ocelot sugiere que la presencia de éste animal no está fuera del contexto histórico. La possibilidad que éste animal representa un grupo de individuos que están escasamente distribuídos dentro los límites historicamente conocidos de ésta especie evasive merece ser considerada.
\end{abstract}

The historical biogeography of the ocelot (Leopardus pardalis) in the United States is sketchy and poorly documented due to the animal's secretive habits and decided preference for dense thickets and rugged terrain, as noted by the earliest observers (Bailey 1905, Strecker 1924). Baird (1857:87) claimed that the ocelot occurred "all through the lower country of Texas, and ranges as far north as Red river," although the basis for the latter part of his statement is not known. The only voucher material previously reported from Texas was the skin of one animal and the skull of another, both obtained for Baird by U.S. Army officers from along the Rio Grande in Eagle Pass, Maverick County. The skin of one kitten and the fluid-preserved body of another also were obtained across the Rio Grande from Brownsville, in Matamoras, Mexico. These materials were reported by Baird (1857) to be deposited with the Smithsonian Institution (catalog numbers $25,129,235,2291$, respectively). Until this report, those specimens represented the only museum records of $L$. pardalis from the United States of which we are aware.

The modern distribution of the ocelot has been mapped as extending from the northern two-thirds of South America into Central America, and along either side of the Mexican Plateau into southern Arizona, most of Texas, and the adjoining parts of Louisiana and Arkansas (e.g.,
Lowery 1974, Hall 1981, Hoffmeister 1986, Sealander and Heidt 1990, Murray and Gardner 1997, Schmidly 2004, Haines et al. 2005). The ocelot is one of the rarest cat species in the United States, with stable resident populations of ca. 80-120 animals presently known only from the southernmost Texas counties of Cameron and Willacy. Field studies on these populations by Michael Tewes and colleagues from Texas A\&M University-Kingsville (e.g., Harveson et al. 2004, Laack et al. 2005, Haines et al. 2005, 2006) have been ongoing since shortly after the species was listed as federally endangered in 1982 by the U.S. Fish and Wildlife Service.

On 28 March 2010, the road-killed body of an adult scrotal male ocelot was retrieved by Texas Parks and Wildlife game warden Matt Waggoner from along Highway 180, ca. $3 \mathrm{~km}$ east of Palo Pinto, Palo Pinto County, Texas $\left(32^{\circ} 46^{\prime} 4.08^{\prime \prime} \mathrm{N}, 98^{\circ} 15^{\prime} 41.4^{\prime \prime} \mathrm{W}\right)$. The terrain in this region is typical for the Western Cross Timbers and consists of limestone and shale, with dense stands of mixed oaks (mostly Quercus marilandica and Quercus stellata) and red cedar (Juniperus virginiana) that extend through north Texas into Oklahoma. Bordered by mesquite savanna to the west and bands of prairie to the east, large tracts of relatively continuous woodlands and heavy brush still persist because the broken and rugged terrain is of little

${ }^{1}$ Department of Biology, Midwestern State University, Wichita Falls, TX 76308. E-mail: frederick.stangl@mwsu.edu

${ }^{2}$ Texas Parks and Wildlife Department, 4200 Smith School Road, Austin, TX 78744. 


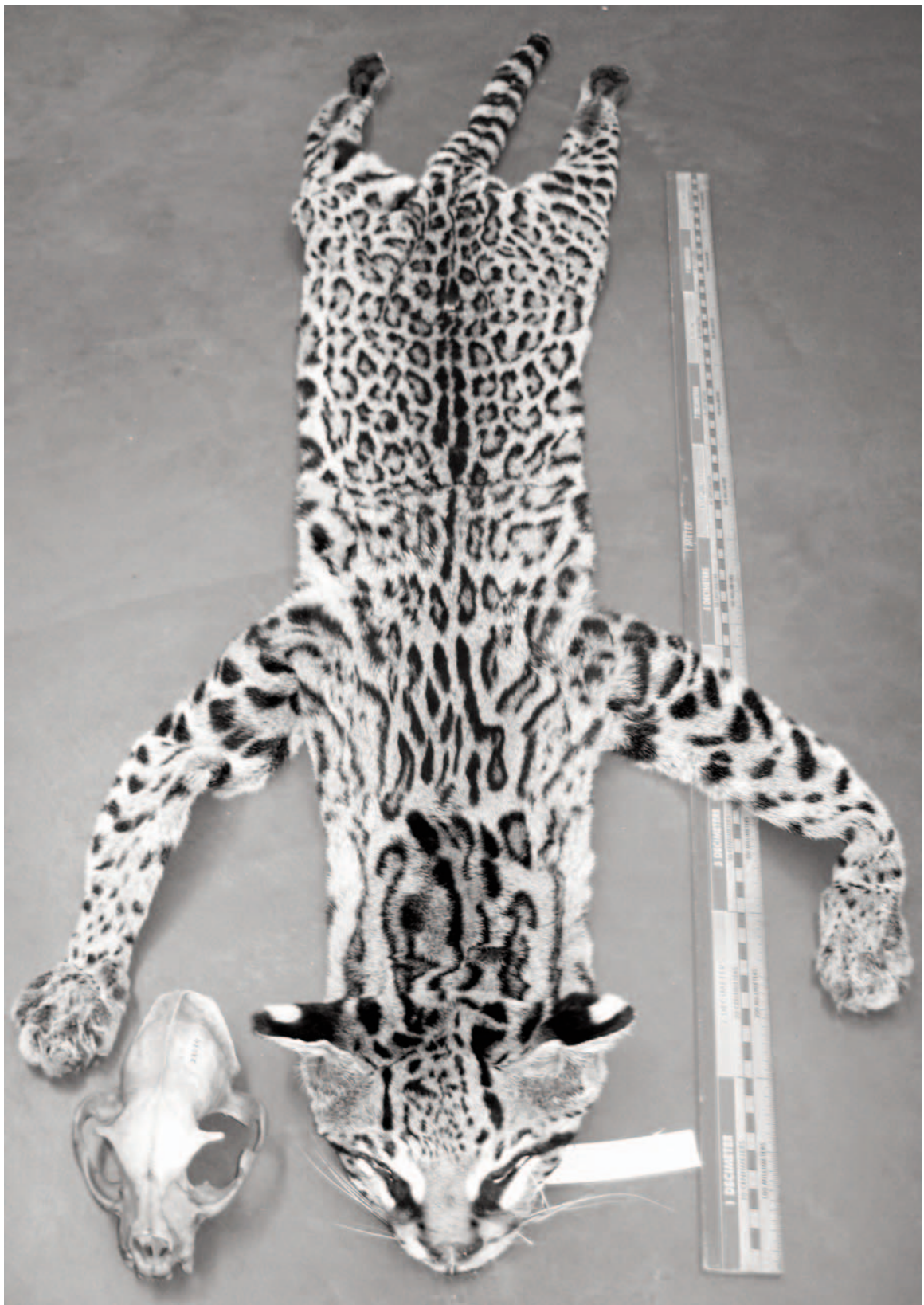

Fig. 1. Tanned hide and skull of Leopardus pardalis (MWSU 23034) recovered from Palo Pinto County, Texas, on 28 March 2010

agricultural value. The Brazos River enters the region near Waco and meanders to the north and west, through Palo Pinto County near the collection site, and beyond to the mesquite savanna of the Rolling Plains.

The ocelot weighed $13.04 \mathrm{~kg}$, and body measurements $(\mathrm{mm})$ were total length, 1220; tail length, 355; hind foot length, 155; and ear length, 55. Selected cranial measurements (mm) were condylobasal length, 130; zygomatic breadth, 96; and postorbital breadth, 34. These measurements place this individual near the upper limits reported for males of the species (Murray and Gardner 1997). The specimen 


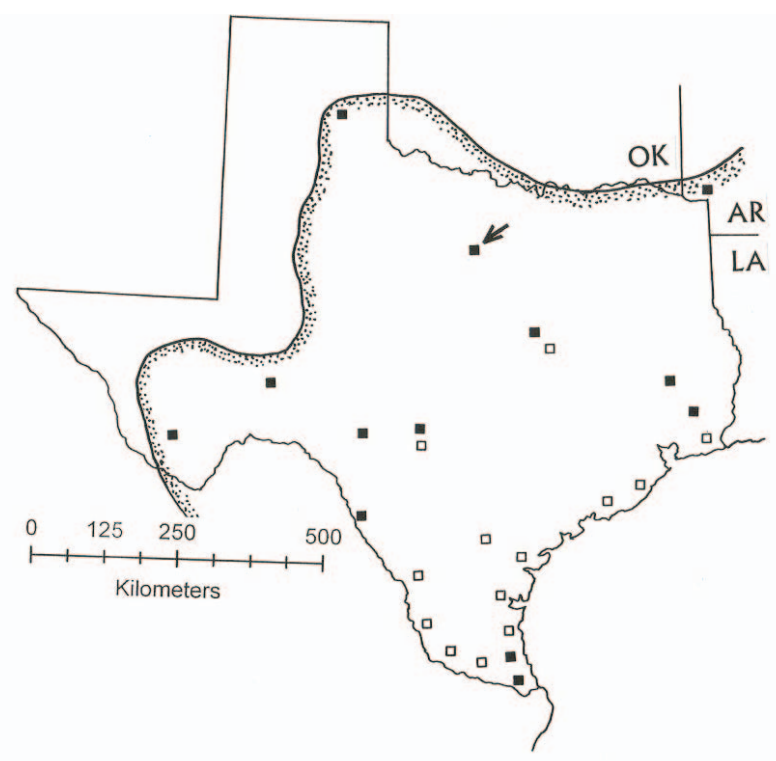

Fig. 2. Historical distribution of Leopardus pardalis in Texas. Solid symbols represent records from Table 1, and open symbols are additional records from Schmidly (2004). Arrow indicates location for the Palo Pinto County specimen reported herein.

was in excellent condition, as judged by its skin being more heavily laden with fat than is typical of bobcats (Lynx rufus) we have taken at comparable times of the year. The cat had clearly been ranging free and foraging successfully for some time, for the flesh side of the pelt revealed the face and venter to be heavily festooned with many hundreds of the fine spines of prickly pear (Opuntia sp.) and tasajillo (Cylindropuntia leptocaulis), especially around the feet and forelegs. The stomach contained 4 small rodents reported as typical fare for the ocelot (e.g., de Villa Meza et al. 2002): 2 Sigmodon hispidus, 1 Peromyscus (c.f. P. leucopus), and 1 Reithrodontomys (c.f. R. fulvescens). The complete skeleton and tanned hide (Fig. 1) are deposited in the Midwestern State University Collection of Mammals (MWSU 23034), and voucher tissues are deposited in the Genetic Resources Collection of Texas Tech University (TK 163819).

\section{Provenance of the Palo Pinto Ocelot}

The detailed provenance of a field-taken or salvaged specimen of any species can seldom be ascertained, but, whether of captive or natural origins, we believe the Palo Pinto ocelot is of Texas-northern Mexico ancestry. The background pelage color of the animal is pale gray, which is characteristic of populations from along and north of the Rio Grande (Murray and Gardner 1997). Also, the animal has a mtDNA haplotype that corresponds to specimens from south Texas and northern Mexico (Janecka et al. 2007, DeYoung and Holbrook 2010).

One of 3 possible scenarios might account for an ocelot in north Texas. First is that the animal simply traversed the $850 \mathrm{~km}$ separating the Palo Pinto locality from known south Texas populations (Fig. 2) - an extraordinary distance for a species with a typical dispersal distance of ca. $10 \mathrm{~km}$ (Haines et al. 2005). A second possibility is that the animal escaped from a captive setting. We note that the species is popular with zoos and exotic pet fanciers, although zoological collections in the nearby Dallas-Fort Worth metroplex (ca. 50-80 km to the east) were not missing an ocelot. There have been no reports from other sources of escaped or missing animals, as might be expected unless the animal was illegally maintained. Finally, a review of the historical record of the species (Table 1) suggests the possibility that the Palo Pinto ocelot might simply represent a secretive and uncommon species of more widespread occurrence across the state than currently suspected. The plausibility of this latter scenario is discussed below. 
TABLE 1. Literature reports for the ocelot (Leopardus pardalis) comprising a basis for a mapped historical range of the species (Hall 1981). Primary references (unless otherwise cited) are for Arizona, Hoffmeister (1986); Arkansas, Sealander and Heidt (1990); Louisiana, Lowery (1974); and Texas, Bailey (1905) and Schmidly (1983).

\begin{tabular}{|c|c|c|c|}
\hline Specific locality & Year & Basis & Comments \\
\hline \multicolumn{4}{|l|}{ ARIZONA } \\
\hline Near Redington, Pima Co. & pre-Columbian & voucher & $\begin{array}{l}\text { Skull from archaeological fauna iden- } \\
\text { tified by Burt (1961) }\end{array}$ \\
\hline Fort Verde, Yavapai Co. & 1887 & voucher & $\begin{array}{l}\text { Skin obtained by E.H. Mearns; depos- } \\
\text { ited at American Museum }\end{array}$ \\
\hline Near Camp Verde, Yavapai Co. & 1932 & verbal account & $\begin{array}{l}\text { Taken by trapper; reported to Arizona } \\
\text { Game and Fish Department }\end{array}$ \\
\hline Near Patagonia, Santa Cruz Co. & 1960 & verbal account & $\begin{array}{l}\text { Taken by hunter; reported to Arizona } \\
\text { Game and Fish Department }\end{array}$ \\
\hline Ski Island region, Cochise Co. & 2009 & photograph & $\begin{array}{l}\text { Remote-sensing camera image from } \\
\text { Sky Island Alliance conservation } \\
\text { group }\end{array}$ \\
\hline Near Globe, Gila Co. & 2010 & voucher & $\begin{array}{l}\text { Road-killed specimen, salvaged by } \\
\text { Arizona Game and Fish Depart- } \\
\text { ment; deposition uncertain at } \\
\text { present time }\end{array}$ \\
\hline \multicolumn{4}{|l|}{ ARKANSAS } \\
\hline Southeastern corner of state & 1855 & voucher & $\begin{array}{l}\text { Type specimen for L. pardalis albes- } \\
\text { cens Pucheran; deposition unknown }\end{array}$ \\
\hline \multicolumn{4}{|l|}{ LOUISIANA } \\
\hline Eastern border of state & $1800 \mathrm{~s}$ & none & $\begin{array}{l}\text { Inferred presence by proximity to } \\
\text { reports from east Texas }\end{array}$ \\
\hline \multicolumn{4}{|l|}{ Texas } \\
\hline Big Thicket region, east Texas & $1700 \mathrm{~s}$ & written account & $\begin{array}{l}\text { Schmidly (1983) recounts early Spanish } \\
\text { recollections of "tiger cats" }\end{array}$ \\
\hline Eagle Pass, Maverick Co. & mid-1800s & voucher & $\begin{array}{l}\text { Baird (1857) reports on skin and skull } \\
\text { in the Smithsonian Institution }\end{array}$ \\
\hline Vicinity of Waco, McLennan Co. & mid-1800s & verbal account & $\begin{array}{l}\text { Strecker (1926) cites trapping records, } \\
\text { fur purchases from vicinity }\end{array}$ \\
\hline Big Thicket, Hardin/Polk counties & late $1800 \mathrm{~s}$ & verbal account & $\begin{array}{l}\text { Baker (1956) relates recollections } \\
\text { of older residents }\end{array}$ \\
\hline McLennan Co. & late $1800 \mathrm{~s}$ & verbal account & $\begin{array}{l}\text { Strecker }(1924) \text { cites reports of occur- } \\
\text { rences along local river bottomlands }\end{array}$ \\
\hline South of Sheffield, Pecos Co. & early 1900s & verbal account & $\begin{array}{l}\text { Bailey }(1905) \text { cites secondhand source } \\
\text { of local occurrence along Pecos } \\
\text { River }\end{array}$ \\
\hline Near Sour Lake, Hardin Co. & 1902 & verbal account & $\begin{array}{l}\text { Bailey (1905) quotes N. Hollister of } \\
\text { several hunter kills }\end{array}$ \\
\hline Near Rock Springs, Edwards Co. & 1902 & verbal account & $\begin{array}{l}\text { Bailey (1905) relates store owner's } \\
\text { account of skin sales }\end{array}$ \\
\hline 10 mi. S Kerrville, Kerr Co. & 1902 & verbal account & $\begin{array}{l}\text { Bailey (1905) relates sheriff's viewing } \\
\text { of skin }\end{array}$ \\
\hline West central Brewster Co. & 1903 & verbal account & $\begin{array}{l}\text { Bailey (1905) reports on and presum- } \\
\text { ably views skin }\end{array}$ \\
\hline 2.5 mi. NE Hedley, Donley Co. & 1950 & photograph & $\begin{array}{l}\text { Davis (1951) cites newspaper account } \\
\text { and photo of ocelot taken by hunter }\end{array}$ \\
\hline Palo Pinto/Young county line & late $1950 \mathrm{~s}$ & verbal account & $\begin{array}{c}\text { This report; } 2 \text { sight records from Waco } \\
\text { Bend of Possum Kingdom Lake }\end{array}$ \\
\hline 3 km E Palo Pinto, Palo Pinto Co. & 2010 & voucher & This report \\
\hline
\end{tabular}

\section{Northern Biogeographic History of Leopardus pardalis}

Pleistocene records for L. pardalis in North America exist only for sites in Florida and the Yucatan of Mexico (Kurten and Anderson 1980,
Murray and Gardner 1997, Arroyo-Cabrales and Polaco 2003), with the Florida records attributed to an earlier northern incursion during the preceding Sangamon interglacial (Werdelin 1985). Burt's (1961) recovery of an ocelot skull 
from a pre-Columbian Arizona archaeological site provides the earliest Holocene record of the species from the United States, for it is not recorded from the many Holocene faunas known from across New Mexico (Harris 1987, 1989), Oklahoma (Davis 1987), or Texas (Graham 1987, Dalquest and Schultz 1992). This chronological gap in the Holocene record may represent sampling error for a rare taxon; but if present, the lack of ocelot records in cave faunas would be somewhat surprising, as the ocelot has been associated closely with caves in Texas for purposes of refuge and rearing young (Bailey 1905). More likely, the ocelot reclaimed parts of its range in Texas during comparatively recent centuries, heralding other documented cases of neotropical advances (e.g., collared peccary, Pecari tajacu; nine-banded armadillo, Dasypus novemcinctus; and pygmy mouse, Baiomys taylori). Two recent records for Arizona (Sky Island Alliance 2010, Arizona Game and Fish Department 2010) may well represent a parallel development for the species in Arizona.

The primary basis for our understanding of the ocelot's historical occurrence in Texas (see Schmidly 2004) remains Bailey's (1905) narrative, although the secretive nature and reluctance of L. pardalis to venture beyond dense cover necessitated his heavy reliance on second-hand accounts. Reported habitat typically varied from the dense tangled woodlands of the Big Thicket region of east Texas to the cedar breaks of central Texas and the dense brush of the rugged Pecos Valley that bisects the Stockton and Edwards plateaus. Clearly, without reference to animals taken by trappers or flushed by hunting packs of hounds, Bailey's contribution would have been greatly impoverished.

Strecker's $(1924,1926)$ accounts indicate that L. pardalis extended its range northward from the broken country of central Texas along this tangled corridor and associated river bottomlands. Early residents of McLennan County (ca. $60 \mathrm{~km}$ SE Palo Pinto) spoke of "long-tailed wildcats" of a distinctly spotted variety frequenting the rugged bottomlands of the Brazos and Tehuacana rivers, along the southeastern margins of the Western Cross Timbers near Waco, Texas (Strecker 1924). These reports apparently were substantiated by a local fur buyer's earlier records from the mid-1850s, which listed "leopard" skins from Indians in the mid-1800s that brought 37-50 cents on the New York fur market (Strecker 1926).

The ocelot has a history in Palo Pinto County that precedes the specimen comprising the basis of this report. One experienced hunter/ naturalist (J.W. Rogers, personal communication), who hunted and fished extensively in the county during the $1950 \mathrm{~s}$, was unsurprised at our record. He related hearing of the species' local existence from other outdoorsmen, and described 2 sightings of his own during the late 1950s. Both incidents occurred while he was fishing along Waco Bend of the Brazos River, just upstream of the Possum Kingdom impoundment. These observations were on the Palo Pinto-Young county line and little more than $30 \mathrm{~km}$ north of the collection site of our specimen. The 1950 specimen reported by Davis (1951) from the rugged Panhandle canyonlands of Donley County, ca. 300 km NW Palo Pinto County, appears less incongruous in this context, given the dispersal avenues afforded by river bottoms of the Brazos and Red river drainages that extend west and northwest from this wooded corridor.

Given the secretive nature of wild felids, even cats as common as the bobcat (Lynx rufus) or as large as the mountain lion (Puma concolor) are seldom observed in a natural setting, and the incidence of outdoor activities relied upon by Bailey (1905) for most of his accounts (e.g., trapping, hunting with hounds) has declined in popularity during recent decades. For these reasons, we see little reason to expect casual sightings or other evidence of resident ocelots to surface on any regular basis, although vigilance for just such an eventuality by field biologists and wildlife professionals is certainly warranted.

We thank Loraine Huddleston of Santo, Texas, for her prompt reporting of the specimen. Palo Pinto game warden Matt Waggoner obtained locality data and transported the animal to Midwestern State University. Jody Mays of the U.S. Fish and Wildlife Service provided many courtesies involved in obtaining the necessary permits. Allan Nelson of Tarleton State University and Mark Howell of Texas Parks and Wildlife played critical roles in procurement of the specimen by Midwestern State University. We recognize Sam Kelley of the U.S. Geological Survey for his detailed observations of the pelt during the tanning 
process. These observations contributed materially to this manuscript. Ken Wilkins of Baylor University kindly provided copies of the Strecker papers, and Magaly Rincon-Zachary provided the Spanish abstract. Comments on earlier versions of the manuscript were offered by Norman V. Horner and Jesse W. Rogers of Midwestern State University. Two anonymous reviews and the editorial input of the Western North American Naturalist staff contributed materially to the finished manuscript.

\section{Literature Cited}

Arizona Game and Fish Department. 2010. Arizona Game and Fish collects ocelot found dead near Globe. [Cited 3 July 2010]. Available from: http://azgfd.net/ artman/publish/News Media/Arizona-Game-andfish-collects-ocelot

Arroyo-Cabrales, J., and O.J. Polaco. 2003. Pages 273-291 in B.W. Schubert, J.I. Mead, and R.W. Graham, editors, Ice Age cave faunas of North America. Indiana University Press, Indianapolis, IN.

BaILey, V. 1905. Biological survey of Texas. North American Fauna 25:1-222.

BAIRD, S.F. 1857. General report on the zoology of the several Pacific Railroad routes, Part I-Mammals, 8: xlvii + 1-757. In: Explorations and surveys for a railroad route from the Mississippi River to the Pacific Ocean. Washington, DC

BAKER, R.H. 1956. Remarks on the former distribution of animals in eastern Texas. Texas Journal of Science 8:356-359.

BuRT, W.H. 1961. A fauna from an Indian site near Redington, Arizona. Journal of Mammalogy 42:115-116.

Dalquest, W.W., AND G.E. SChultZ. 1992. Ice Age mammals of northwestern Texas. Midwestern State University Press, Wichita Falls, TX

DAVIS, L.C. 1987. Late Pleistocene/Holocene environmental changes in the Central Plains of the United States: the mammalian record. Pages 88-143 in R.W. Graham, H.A. Semken Jr., and M.A. Graham, editors, Late Quaternary mammalian biogeography and environments of the Great Plains and Prairies. Illinois State Museum Scientific Papers 22: xiv + 1-491.

DAvis, W.B. 1951. Unusual record of the ocelot in Texas. Journal of Mammalogy 24:363.

de Villa Meza, A., E. Martinez Meyer, and C.A. Lopez GonZALEZ. 2002. Ocelot (Leopardus pardalis) food habits in a tropical deciduous forest of Jalisco, Mexico. American Midland Naturalist 148:146-154.

DeYoung, R., AND J. Holbrook. 2010. Analysis and interpretation of ocelot maternal lineages from road-killed ocelots in Texas and Arizona. Technical report, Texas Parks and Wildlife Department, Austin, TX. 12 pp.

GrAHAM, R.W. 1987. Late Quaternary mammalian faunas and paleoenvironments of the Southwestern Plains of the United States. Pages 24-86 in R.W. Graham, H.A. Semken Jr., and M.A. Graham, editors, Late Quaternary mammalian biogeography and environ- ments of the Great Plains and Prairies. Illinois State Museum Scientific Papers 22: xiv + 1-491.

Haines, A.M., M.E. Tewes, L.L. LaAcK, W.E. Grant, AND J. YounG. 2005. Evaluating recovery strategies for an ocelot (Leopardus pardalis) population in the United States. Biological Conservation 126:512-522.

Haines, A.M., M.E. Tewes, L.L. LaACK, J.S. Horne, and J.H. YounG. 2006. A habitat-based population viability analysis for ocelots (Leopardus pardalis) in the United States. Biological Conservation 132:424-436.

Hall, E.R. 1981. The mammals of North America. Volume 2. John Wiley \& Sons, New York, NY.

HARRIS, A.H. 1987. Reconstruction of mid-Wisconsin environments in southern New Mexico. National Geographic Research 3:142-151.

1989. The New Mexican Late Wisconsin-east versus west. National Geographic Research 5:205-217.

Harveson, P.M., M.E. Tewes, G.L. Anderson, and L.L. LAACK. 2004. Habitat use by ocelots in south Texas: implications for restoration. Wildlife Society Bulletin 32:948-954.

Hoffmeister, D.F. 1986. Mammals of Arizona. University of Arizona Press, Tucson, AZ.

Janecka, J.E., C.W. Walker, M.E. Ewes, A. Caso, L.L. LAaCK, AND R.L. HoneycutT. 2007. Phylogenetic relationships of ocelot (Leopardus pardalis albescens) populations from the Tamaulipan Biotic Province and implications for recovery. Southwestern Naturalist 52:89-96.

Kurten, B., And E. Anderson. 1980. Pleistocene mammals of North America. Columbia University Press, New York, NY.

Laack, L.L., M.E. Tewes, A.M. Haines, and J.H. RaPPOLE. 2005. Reproductive life history of ocelots Leopardus pardalis in southern Texas. Acta Theriologica 50:505-514.

Lowery, G.H., JR. 1974. The mammals of Louisiana and its adjacent waters. Louisiana State University Press, Baton Rouge, LA.

MurRaY, J.L., AND G.L. GARDNER. 1997. Leopardus pardalis. Mammalian Species 548:1-10.

SchmidLY, D.J. 1983. Texas mammals east of the Balcones Fault Zone. Texas A\&M University Press, College Station, TX.

2004. The mammals of Texas. University of Texas Press, Austin, TX

SEalander, J.A., And G.A. Heidt. 1990. Arkansas mammals: their natural history, classification, and distribution. University of Arkansas Press, Fayetteville, AR.

SKY IsLAND ALLIANCE. 2010. Rare tropical cat found alive in Arizona. [Cited 3 July 2010]. Available from: http://www.skyislandalliance.org/ocelot-news.htm

Strecker, J.K. 1924. The mammals of McLennan County, Texas. Baylor Bulletin 27:1-20.

1926. The mammals of McLennan County, Texas: supplementary notes. Contributions, Baylor University Museum 9:1-15.

Werdelin, L. 1985. Small Pleistocene felines of North America. Journal of Vertebrate Paleontology 5: 194-210.

Received 30 April 2010 Accepted 12 April 2011 